
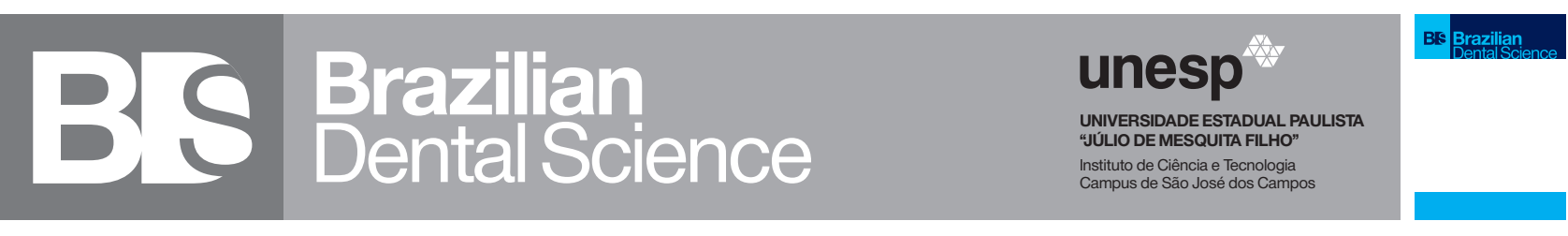

\title{
Estimation of time utilized in suturing of oral flaps post-surgical wisdom teeth removal using Negus knot pusher instrument (a comparative study)
}

Estimativa do tempo utilizado na sutura de retalhos orais após exodontia de terceiros molares utilizando o instrumental Empurrador de nó Negus: um estudo comparativo

Noor SULAIMAN ${ }^{1}$, Ziad DELEME ${ }^{1}$, Saif ALI ${ }^{1}$

1 - Department of oral and maxillofacial surgery, College of Dentistry, Mosul University, Mosul, Iraq.

\section{ABSTRACT}

Objective: Wisdom teeth were the most common teeth affected among the rest of the teeth, these teeth need accurate evaluation and diagnosis, surgical removal of impacted wisdom needs time for incision, bone removal and suture, so the use of any instrument helps to reduce this time is essential. The objectives of this study were to estimate the time needed for the suture of oral flaps post-surgical removal of the lower wisdom teeth by using Negus knot pusher and compare it with the time used for stitching in conventional manual holding single stitching. Material and Methods: Data had been collected from thirty patients through history, clinical examination and radiographic assessment, followed by classical surgical removal performed on the same principles for all patients, at the suture level patients divided arbitrarily into two groups, control group 15 patients and 15 patients Negus pusher group, using Negus knot pusher, which is usually used to hold the stitch and stop bleeding post tonsillectomy operations by ligation, time elapsed for suturing with knot tying is calculated for both groups. Results: Among the 30 patients incorporated in the clinical study, control group mean was (1 minutes and 11 seconds and 70 milliseconds) while for the pusher group was (1 minutes and 32 seconds and 57 milliseconds), the comparison by means of T-test was not significant with the (0.424) value. Conclusion: the Negus pusher instrument can be used for the knotting stiches post wisdom teeth removal as an auxiliary tool and the time can be shortened by the use of a modified handling technique and more satisfaction for patients.

\section{KEYWORDS}

Time; Suturing; Wisdom teeth; Negus knot pusher.

\section{RESUMO}

Objetivo: Os terceiros molares são os dentes mais afetados entre o resto dos dentes e necessitam de avaliação e diagnóstico precisos. A exodontia desses elementos impactados requer tempo para incisão, remoção óssea e sutura, portanto, é essencial o uso de instrumentos que ajudem a reduzir o tempo de procedimento. Os objetivos do presente estudo foram estimar o tempo necessário para a sutura de retalhos orais após a exodontia de terceiros molares inferiores utilizando o instrumental Empurrador de nó Negus (Negus Knot pusher) e compará-lo com o tempo necessário para a realização de sutura única convencional. Material e Métodos: Os dados foram coletados de 30 pacientes através da história, exame clínico e avaliação radiográfica, seguidos pela remoção cirúrgica clássica realizada através do mesmo princípio para todos os pacientes. Considerando o nível da sutura, os pacientes foram divididos arbitrariamente em dois grupos, grupo controle $(n=15)$ e grupo Empurrador de nó Negus $(n=15)$, o qual é geralmente utilizado para segurar o ponto e estancar o sangramento após cirurgia de tonsilectomia por ligadura. O tempo decorrido para sutura foi calculado para ambos os grupos. Resultados: Entre os 30 pacientes incluídos no estudo, a média do grupo controle foi de 1 minuto e 11 segundos e 70 milissegundos, enquanto para o grupo Empurrador de nó Negus foi de 1 minuto e 32 segundos e 57 milissegundos. A comparação intergrupo por meio do teste $\mathrm{T}$ não foi estatisticamente significativa $(\mathrm{p}=0,424)$. Conclusão: $\mathrm{O}$ instrumental Empurrador de nó Negus pode ser usado para sutura após a extração de terceiros molares como ferramenta auxiliar e o tempo pode ser reduzido pelo uso de uma técnica de manuseio modificada. Ademais, pode estar associado a maior satisfação dos pacientes.

\section{PALAVRAS-CHAVE}

Tempo; Sutura; Terceiro molar; Empurrador de nó negus. 


\section{INTRODUCTION}

$\mathrm{T}$ hird molar extraction is frequent minor intraoral surgical procedure [1]. Most common causes for wisdom teeth removal comprise pathological dental caries, opercular tissue inflammation, periodontal problems, cystic pathology, and orthodontic problems. It is recommended to perform extraction of third molars primarily to avoid upcoming complications or extreme inclination [2]. The exact time to decide removal wisdom teeth or not is under discussion, given the impact predictions and supporting the idea of the prophylactic extraction of wisdom teeth, even in adulthood period in spite of dispute between the orthodontist and oral maxillofacial surgeons in the subject of early surgical prophylactic removal of wisdom teeth [3-7]. In addition, surgeons must be able to deal with the surgical consequences during and following wisdom teeth removal which include intolerable pain, edema, hemorrhage, alveolar dry socket, pus formation, dehiscence, sequester numbness, blood collection, and limited mouth opening [8]. Post-surgical pain and edema is important factors in surgical wound curing, and use of minimal sutures with smaller diameters or utilizing anchor suture is recommended. Tight suturing and intimate flap closer leads to post-surgical distress [9-12]. Black silk suture is favorite suturing material to bring together the borders of the wound post-surgery due to simplicity of handling, less inflammation and node safety. So suturing leads to hold of bleeding and promote of primary wounds healing [13]. Knot pushers tool are utilized with intra-articular descending ties and are at no time used with exposed surgical work as it is simply to be done handily [14]. Numerous knot pusher instruments had been presented to simplify suture knot tightening. Existing commercial obtainable designs comprise of either an indentation or a loop tip to engage, advance and lock the tie $[15,16]$. Commercial node pusher tools are rod-shaped and necessitate a helper to grasp one end of the suture as the surgeon pushes the node inferiorly [17]. The perfect nodepusher scheme must have had a termination that is slight enough to prevent the node from snagging. However, if large adequately to permit the diameter of suture to pass easily. 'Snagging' is the propensity of the node to be trapped in the pusher as the node is squeezed [18]. The Negus Knot Pusher instrument is used for vascular bundle ligation in the tonsillectomy procedure to control intraoperative bleeding and to reduce postoperative bleeding, so that it can reach a deep point in the retromolar trigon or oropharyngeal area and for this reason we choose using this instrument in our study and get benefit of time elimination during operative work specially in cases operated under local anaesthesia and need intraoral suturing with minimal time as possible.

The aims of this study were to estimate the time needed for suturing with and without uses of Negus knot pusher in operative removal of lower wisdom teeth, and to calculate the time if the pusher used to shorten the total time of the operation as the lower wisdom tooth located at retromolar trigon area which regarded as the most posterior part of oral cavity specially in limited mouth opening cases.

\section{MATERIALS AND METHODS}

A clinical research was conducted between April 2018 and December 2019 at the College of Dentistry / Mosul University. This study includes thirty cases of both male and female presented to the Oral and MaxFax Departments complaining of ache (pain) in either the lower right or left quadrant of the jaw with partially or completely affected lower third molar after taking (current illness, past medical and past dental) clinical and radiographic history (Periapical radiography, OPG and CBCT) Evaluation of the difficulty of the case according to Bell and Gregory classification was carried out, the inclusion criteria for the 
incomplete bone covering of the mandibular third molars with "Class II or III and position A, B or C," on the periapical radiography. With age of 18 years or older, with no inflammation of opercular tissues, utilizing enveloped flap that need single stich in all cases. Exclusion criteria included patients with a history of compromised health, pregnant or breast feeding female, or cases that need more than one stiches. Surgical procedure for the removal of the affected lower third molar started with local anesthesia block to inferior alveolar nerve with long buccal nerve infiltration followed by a crestal incision extending from half of the external oblique ridge to the distal to the lower second molar with no vertical releasing incision, dissection of the buccal mucogingival (envelope) flap by Haworth mucogingival elevator, buccal bone removal by round hand bur with irrigation by diluted Chlorhexidine $0.2 \%$ irrigation solution to prevent heat generation from creating space for impact tooth to be removed by elevators and forceps with or without a surgical separation of the crown and roots of any remaining bone spicules or soft tissue follicle removed, only single stitch suture made of black silk suture 3:0 with simple interrupted suturing technique posterior to lower second molar by the same operator for all patients, at this stage cases were allocated into group 1 (control 15 patients) stitching in conventional suturing hand knot tying simple interrupted suture without a pusher instrument using, and group 2 (15 patients as pusher group) using Negus knot pusher as shown in Figure (2), the both ends of suture were held only by the surgeon himself by using a modified pusher handling method, in which grasping the pusher at two sites by first and second fingers, and between the tips of the third and fourth fingers, allowing the second and third fingers to grasp one of the ends of the stich. By this maneuver tightness of stich is controlled by surgeon and by using right hand at distal third of the shaft handle and the two threads of suture inserted in the slot of pusher and advanced till touch the knot then starts to push till the knot became in the exact position needed with suitable tightening of knot without blanching the neighboring tissue flaps as shown in figure (3) and the time needed for each knotting technique was saved by timekeepers whom the same with the surgeon throughout the study by using smart phone time stopwatch in android application as shown in figure (4), the time from the start from clasping the needle in the needle holder to the end of the stitching by cutting threads is calculated by two timekeepers and recorded for all cases, so the time was the main parameter utilized in this study. Statistical analysis: as the data for this study are numbers (mean time) continuous numerical data were expressed as mean and standard deviations (SD), The data was compared with the independent T-test sample. A value of less than 0.05 was considered to be significant.

\section{RESULTS}

Thirty patients included in the study with [15] for each group, the mean for each group was calculated and the standard deviation was also detected, the mean for the group that did not use the pusher for suture was ( 1 minutes and 11 seconds and 70 milliseconds) while for the group in which the Negus pusher used for suture was ( 1 minutes and 32 seconds and 57 milliseconds), the comparison between two groups excluded by the T-test was not significant with (0.424). As shown in Table I and Figure (1).

Table I - Mean and standard deviation of both groups

\begin{tabular}{|c|ccc|}
\hline Groups & Mean & SD & PValue * \\
\hline Control & 1m.11s.70ms & 00.25 .33 & \\
\hline Pusher & $1 \mathrm{~m} .32 \mathrm{~s} .57 \mathrm{~ms}$ & 00.19 .61 & 0.424 \\
\hline
\end{tabular}

${ }^{*} \mathrm{P}$ value $\leq 0.05$ was significance, $\mathrm{m}=$ minutes, $\mathrm{s}=$ seconds, $\mathrm{ms}=$ milliseconds. 


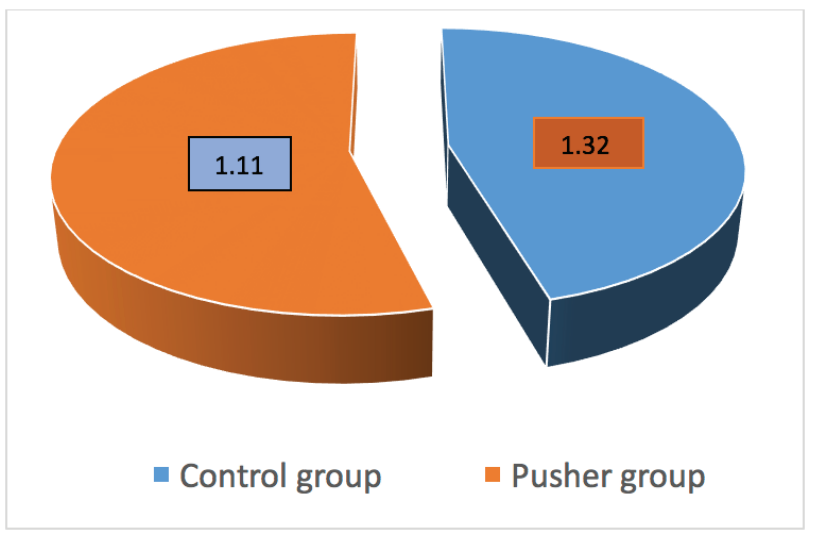

Figure 1 - Pie shows the differences in time mean between 2 groups.

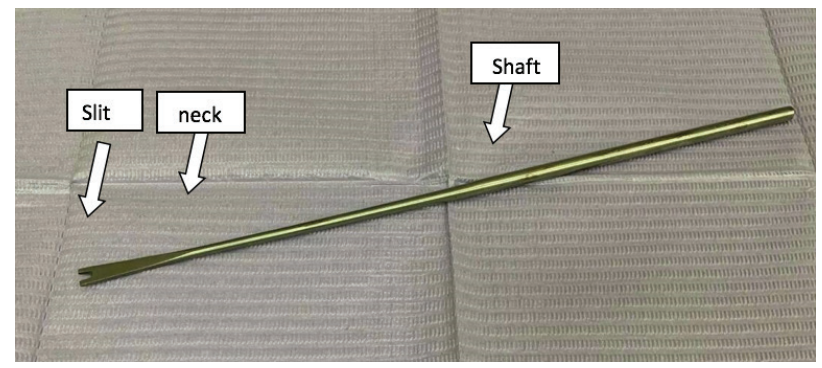

Figure 2 - Negus knot pusher instrument utilized in the study with its parts.



Figure 3 - Pusher in use intra-orally.

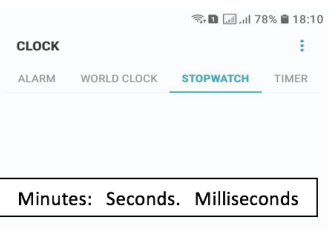

staRt

Figure 4 - Time calculation in android smart phone.

\section{DISCUSSION}

The operative work in conscious patient is a challenging matter specially to oral and maxillofacial surgeon whom work mostly under local anesthesia and more tension and apprehensive circumstances and in limited visibility in intraoral surgical work. So such a practice that requires practical expertise, thorough decision and awareness of detailed structures and surgical tricks [19]. Node pusher tools had been used in a variety of endoscopic surgery, with some modifications in Shape and technical use [20]. The strength of the knot was determined to be the force required for the knot to slip or break [21]. Irrespective of the type of suture or method of suturing, usage of a node increases knot tightness. A node pusher tool should improve node tightness in descending nodes through endoscopic surgery and in performing one-handed knotting in open work [14]. During daily surgical dental work and specially post wisdom surgery, working by hands and using only needle holder and pins twisser usually associated with difficulties in application and performing ideal stiches with secure knotting and less harmful effect to the adjacent tissues and flap to obtain optimal healing with minimal side effects [20]. In this study, the node pusher used in the field of oral surgery as an assistant device and the time needed for suture was calculated in two groups with and without the use of a pusher. Although the mean time was higher slightly in pusher group patients in comparison with control group, this may be related to unfamiliarity with this instrument, Since we have not found any research or article similar to ours so we rely on some research that uses pusher in different ways, there are many factors that reveal or disclose this result, all procedures in this study have been performed under local anesthesia so that this may increase the patient's gag reflexes and apprehension in particular, the instrument enters deep into the patient's mouth and difficulty in getting cooperation in the opening of the mouth 
and this cannot be avoided for all patients [15], a modifications done in knot pusher which used a special design in laparoscopic procedures with a central deep slit at the end with a channel lengthwise the underside of the pusher tube to support the stitch running smoothly and quickly, when the knot was occasionally detached, so easily re attached again without affecting the stiches or flap, and without slipping ligatures while knotting. In 2017 Fung-Chao study showed using a pusher with two components working and pusher parts in laparoscopic procedures and stated that "knotting time in the device group was shorter than in the sliding and static groups" [21]. And in 2015 Nazareth and Papazian et al used a special pusher (Papazian pusher) with angulation at the tip of the pusher. Harmony with oral cavity anatomy in the cleft palate and stated that "no complications were encountered and no knots were found to be, overall, easier, faster and more reliable than knots to push manually while significantly helping to achieve stronger, smoother and more secure knots" [20].

\section{CONCLUSION}

Negus knot pusher tool can be used as an adjunctive instrument in the suturing of intraoral mucoperiosteal flaps post wisdom teeth removal and time may be shortened by the use of modified handling technique, especially in cases of limited mouth opening, and in apprehensive patients or with gagging reflex patients or in unexpected extended time operations, it is considered to be an auxiliary instrument that aids in the suture finishing of secure knots with appropriate strength with minimal time and bothering of the patients and operator in equal and we recommend to add this nice simple tool to our set to get maximum benefits.

\section{Acknowledgments}

The authors are grateful to college of Dentistry university of Mosul for content contributions, and for their critical review of the manuscript and the help us in gathering the cases and for support during the development and writing of this manuscript.

\section{Funding}

This study was totally self-funded.

\section{Conflict of interest}

The authors have no proprietary, financial, or other personal interest of any nature or kind in any product, service, and/or company that is presented in this article.

\section{Regulatory Statement}

This study was conducted in accordance with all the provisions of the local human subject's oversight committee guidelines and policies of: local scientific committee in college of dentistry university of Mosul. The approval code for this study is: 209 in 25-9-2018.

\section{REFERENCES}

1. Friedman J. The prophylactic extraction of third molars: a public health hazard. Am J Public Health. 2007;97(9):1554-9.

2. Cunha-Cruz J, Rothen M, Spiekerman C, Drangsholt M, McClellan L, Huang GJ. Northwest practice-based research collaborative in evidence-based dentistry. Recommendations for third molar removal: a practice-based cohort study. Am J Public Health. 2014;104(4):735-43.

3. Costa M, Pazzini C, Pantuzo M, Jorge M, Marques L. Is there justification for prophylactic extraction of third molars? A systematic review. Braz Oral Res. 2013;27(2):183-8.

4. Mettes TD, Ghaeminia H, Nienhuijs ME, Perry J, van der Sanden WJ, Plasschaert A. Surgical removal versus retention for the management of asymptomatic impacted wisdom teeth. Cochrane Database Syst Rev. 2012 Jun 13:(6):CD003879. doi:101002/14651858.CD003879.pub3. Update in: Cochrane Database Syst Rev. 2016;8:CD003879. PMID: 22696337.

5. Lindauer SJ, Laskin DM, Tüfekçi E, Taylor RS, Cushing BJ, Best AM. Orthodontists' and surgeons' opinions on the role of third molars as a cause of dental crowding. Am J Orthod Dentofacial Orthop. 2007 Jul;132(1):43-8. doi:10.1016/j.ajodo.2005.07.026.PMID:17628249.

6. Normando D. Third molars: To extract or not to extract? Dental Press J Orthod. 2015 Jul-Aug;20(4):17-8. doi:10.1590/2176-9451.20.4.017-018.edt. PMID: 26352839; PMCID:PMC4593524.

7. Sigron GR, Pourmand PP, Mache B, Stadlinger B, Locher MC. The most common complications after wisdom-tooth removal: part 1: a retrospective study of 1,199 cases in the mandible. Swiss Dent J. 2014;124(10):1042-6, 1052-6.

8. Lee CT, Zhang S, Leung YY, Li SK, Tsang CC, Chu CH. Patients' satisfaction and prevalence of complications on surgical extraction of third molar. Patient Prefer Adherence. 2015 Feb 10; 9:257-63. doi: 10.2147/PPA.S76236. 
9. Khande K, Saluja H, Mahindra U. Primary and secondary closure of the surgical wound after removal of impacted mandibular third molars. $J$ Maxillofac Oral Surg. 2011 Jun;10(2):112-7. doi: 10.1007/s12663-011-0216-y. Epub 2011 Apr 22.

10. Delemi ZH. The use of three different suturing techniques for wound closure of mucoperiosteal flaps after surgical removal of impacted lower wisdom teeth (comparative study). Al-Rafidain Dent J. 2017(1): 98-107.doi: 10.33899/ rden.2016.164143.

11. Van Gool AV, Ten Bosch JJ, Boering G. A photographic method of assessing swelling following third molar removal. Int J Oral Surg. 1975 Jul;4(3):121-9. doi: 10.1016/s0300-9785(75)80004-4.

12. de Brabander $E C$, Cattaneo $G$. The effect of surgical drain together with a secondary closure technique on postoperative trismus, swelling and pain after mandibular third molar surgery. Int J Oral Maxillofac Surg. 1988 Apr;17(2):119-21. do: 10.1016/s0901-5027(88)80164-4.

13. Rodanant P, Wattanajitseree K, Shrestha B, Wongsirichat N. Pain and quality of life related to suture removal after 3 or 7 days at the extraction sites of impacted lower third molars. J Dent Anesth Pain Med. 2016 Jun;16(2):131-6. doi:10.17245/jdapm.2016.16.2.131.

14. Arango D, Narvaez MV, Sweitzer B. Utilization of knot pusher increases knot security for sliding and static knots. J Am Coll Surg 2017;225(4 Sup11):S145-6. doi:https://doi.org/10.1016/j.jamcollsurg.2017.07.328
15. Barto W, Chen S. Improved design knot pusher for laparoscopic extracorporeal suturing. ANZ J Surg. 2003 Mar;73(3):162. doi: 10.1046/j.14452197.2003.02648.x. PMID: 12608982

16. Tomkinson A, Harrison W, Owens D, Harris S, McClure V, Temple M. Risk factors for postoperative hemorrhage following tonsillectomy. Laryngoscope. 2011Feb;121(2):279-88. doi: 10.1002/lary.21242.

17. Yim AP,Lee TW. 'Homemade' knot pusher for extracorporeal ties. AustNZJ Surg. 1995 Jul;65(7):510-1. doi: 10.1111//.1445-2197.1995.tb01797.x.

18. Kerin C, Patel N, Bale RS, Fisher AC, Hughes PJ. Arthrosopic knot pushers. Does one size fit all? Int J Clin Pract. 2008 May;62(5):747-9. doi:10.1111/.j.17421241.2006.01263. $x$.

19. Chaudhary M, Singh M, Singh S, Singh SP, Kaur G. Primary and secondary closure technique following removal of impacted mandibular third molars: A comparative study. Natl J Maxillofac Surg. 2012 Jan;3(1):10-4. doi: 10.4103/0975-5950.102141.

20. Papazian NJ, Chahine F, Atiyeh B, Deeba S, Zgheib E, Abu-Sittah G Introduction of "Papazian Pusher: "A Modified-Design Knot Pusher for Surgical Repair of Cleft Palates. J Craniofac Surg. 2015 Sep;26(6):1975-6. doi: 10.1097/SCS.0000000000001926. PMID: 26355980

21. Tu FC, Sun HD, Ting WH, Wu WY, Lin HH, Hsiao SM. Optimizing Laparoscopically Extracorporeal Knot Tying Using a Novel Pusher Device. Surg Laparosc Endosc Percutan Tech. 2017 Jun;27(3):e31-e35. doi: 10.1097/ SLE.0000000000000398.

Noor A. Sulaiman

(Corresponding address)

Department of oral and maxillofacial surgery, College of Dentistry,

Mosul University, Mosul, Iraq.

Email: noorabdullah@uomosul.edu.iq

Date submitted: 2020 Nov 22

Accept submission: 2021 Mar 22 